\title{
BIODEGRADATION OF REMAZOL BRILLIANT BLUE R BY LIGNINOLYTIC ENZYMATIC COMPLEX PRODUCED BY PLEUROTUS OSTREATUS
}

\author{
Kátia Maria Gomes Machado1*; Dácio Roberto Matheus ${ }^{2}$ \\ ${ }^{1}$ Curso de Ciências Biológicas, Universidade Católica de Santos, Santos, SP, Brasil; ${ }^{2}$ Seção de Micologia e Liquenologia, \\ Instituto de Botânica, São Paulo, SP, Brasil
}

Submitted: August 23, 2005; Returned to authors for corrections: March 13, 2006; Approved: July 18, 2006

\begin{abstract}
Pleurotus ostreatus ("shimeji”) is produced in Brazil on a commercial scale using various lignocellulosic residues. Efforts have been made to reuse the culture residue to obtain products of greater aggregate value such as enzymes or in processes of bioremediation. We evaluated the Remazol brilliant blue R (RBBR) degradation potential of extracts from solid substrate colonized by $P$. ostreatus and extracts from residue of the "shimeji" mushroom yield. Colonized substrates and residue were provided by Toyobo do Brasil Ltda. Extraction was performed with sodium acetate buffer $(50 \mathrm{mM}, \mathrm{pH} 4.6)$. RBBR decolorization was monitored at $592 \mathrm{~nm}$ and peroxidase and laccase activities were measured by monitoring the oxidation of ABTS. Horseradish peroxidase was used as reference. The time of growth of $P$. ostreatus influenced RBBR degradation and peroxidase and laccase activities. Concentration of $1 \mathrm{mM} \mathrm{H}_{2} \mathrm{O}_{2}$ and $\mathrm{pH} 4.0$ were the best for $\mathrm{RBBR}$ decolorization. Complete RBBR decolorization was obtained with the addition of only one aliquot of $50 \mu \mathrm{L}$ of $1 \mathrm{mM} \mathrm{H}_{2} \mathrm{O}_{2}$. The stability of the extracts was higher when they were kept under refrigeration than when stored frozen. The potential application of the ligninolytic complex derived from P. ostreatus and mushroom residue for xenobiotic degradation was demonstrated.
\end{abstract}

Key words: peroxidases, laccase, solid-state fermentation, "shimeji" culture residue

\section{INTRODUCTION}

The potential application of the ligninolytic complex of basidiomycetes has been the target of great academic and industrial interest due to its ability to biodegrade a series of toxic and recalcitrant pollutants such as DDT, polychlorinated biphenyls, organochlorine pesticides, and various synthetic dyes. These enzymes find various applications in the environmental area, such as the decolorization of effluents from the paper and textile industries and in the polymerization of chlorinated compounds $(5,28)$.

Pleurotus ostreatus or "shimeji" is a mushroom produced in Brazil on a commercial scale using different lignocellulosic residues. During growth, this fungus selectively degrades lignin and produces various extracellular enzymes involved in ligninolysis: laccase, $\mathrm{Mn}^{2+}$-dependent peroxidase $(\mathrm{MnP})$ and
$\mathrm{H}_{2} \mathrm{O}_{2}$-producing oxidases, in addition to other $\mathrm{Mn}^{2+}$ independent peroxidases, such as one able to decolorize Remazol brilliant blue R (RBBR) and versatile peroxidase $(7,11,22)$. Like other basidiomycetes, P. ostreatus is able to degrade a series of synthetic dyes, pentachlorophenol, and polycyclic aromatic hydrocarbons such as phenanthrene, anthracene and pyrene, among other pollutants $(2,13,19)$.

After mushroom harvesting, large volumes of residue (an estimated $600 \mathrm{~g}$ of residue per $200 \mathrm{~g}$ of mushroom) need to be disposed of, representing a large problem for the producer. In addition to fungal mycelium and unused lignocellulosic substrate, the residue contains a series of extracellular enzymes produced during the growth of the fungus. Efforts have been made to reuse this residue to obtain products of higher aggregate values such as biogas, enzymes, organic fertilizers and animal feed supplements, and in processes of bioremediation $(16,20,23)$.

*Corresponding Author. Mailing address: Curso de Ciências Biológicas, Centro de Ciências da Educação, Universidade Católica de Santos, Av. Conselheiro Nébias, 300. 11015-002, Santos, SP, Brasil. Tel.: (+5513) 3205-5555. E-mail: katia@unisantos.br 
RBBR has been widely used as a model compound in degradation studies. It is the raw material in the production of polymeric dyes and, as a derivative of anthracene, represents an important member of toxic and recalcitrant organopollutants. The identity of enzymes involved in the degradation of RBBR is still not completely established, with evidence indicating the involvement of lignin peroxidase and laccases $(4,17,24)$.

In the present study, we evaluated the potential of the ligninolytic complex produced by $P$. ostreatus during growth on solid substrate and of the production residue of this mushroom for the degradation of organic pollutants by determining RBBR decolorization.

\section{MATERIALS AND METHODS}

\section{Enzymatic extracts}

Three polypropylene flasks containing about $1 \mathrm{~kg}$ of substrate (commercial supplemented sawdust) colonized with P. ostreatus grown for 20,25 and 28 days and the residue of "shimeji" mushroom production were provided by Toyobo do Brasil Ltda. Extraction was performed with $50 \mathrm{mM}$ sodium acetate buffer, $\mathrm{pH} 4,6$, at a ratio of 1:3 (w/v). The content was shaken manually (5 $\mathrm{min}$ ) and mechanically (100 rpm, $60 \mathrm{~min}$ ) and filtered $(0.45 \mu \mathrm{m})$ to obtain the crude enzymatic extract. Partially purified horseradish peroxidase (HRP) extract provided by Toyobo was used as reference.

\section{Enzymatic activities}

Peroxidases. Peroxidase activity was determined by monitoring the oxidation of ABTS at $420 \mathrm{~nm}$ for $10 \mathrm{~min}$ in a reaction mixture containing $600 \mu \mathrm{L}$ of the extract, $250 \mu \mathrm{L} 50 \mathrm{mM}$ citrate-phosphate buffer, $\mathrm{pH} 4.0,100 \mu \mathrm{L} 5 \mathrm{mM}$ ABTS, and $50 \mu \mathrm{L}$ $2 \mathrm{mM} \mathrm{H}_{2} \mathrm{O}_{2}$. One unit of enzyme activity was defined as the amount of enzyme oxidizing $1 \mu \mathrm{mol}$ of substrate per liter per minute (10).

Laccase. Laccase activity was determined as described for peroxidases in the absence of $\mathrm{H}_{2} \mathrm{O}_{2}$ using the enzymatic extract previously incubated with Aspergillus oryzae catalase $(0.07 \mathrm{U}$; Sigma).

$R B B R$ decolorization. Decolorization of RBBR was monitored at $592 \mathrm{~nm}$ for $10 \mathrm{~min}$ in a reaction mixture containing $600 \mu \mathrm{L}$ of the extract, $250 \mu \mathrm{L} 50 \mathrm{mM}$ citrate-phosphate buffer, $\mathrm{pH} 4.0,100 \mu \mathrm{L} 0.2 \% \mathrm{RBBR}$, and $50 \mu \mathrm{L} 2 \mathrm{mM} \mathrm{H}_{2} \mathrm{O}_{2}$. One unit of decolorization activity was defined as that able to catalyze a 0.01 reduction in absorbance (10).

\section{Determination of the optimal $\mathrm{H}_{2} \mathrm{O}_{2}$ concentration and $\mathrm{pH}$ optimum}

The optimal $\mathrm{H}_{2} \mathrm{O}_{2}$ concentration for RBBR decolorization by the 25-day $P$. ostreatus extract was determined in the range of 0.025 to $2.5 \mathrm{mM}$ using the reaction kinetics described above.
The $\mathrm{pH}$ optimum for RBBR decolorization by the 25-day $P$. ostreatus extract was determined in the range of 3 to 7 using 50 $\mathrm{mM}$ sodium citrate buffer.

\section{Successive additions of $\mathrm{H}_{2} \mathrm{O}_{2}$ and RBBR}

The effects of successive additions of $50 \mu \mathrm{L}$ of $1 \mathrm{mM} \mathrm{H}_{2} \mathrm{O}_{2}$ and $100 \mu \mathrm{L}$ of $0.2 \%$ RBBR on the decolorization of the latter by the 25-day P. ostreatus extract were evaluated based on the absorption spectrum of RBBR (400 to $700 \mathrm{~nm}$ ). HRP was used as reference.

\section{Effect of inhibitors}

Decolorization of RBBR by the extract of $P$. ostreatus grown for 25 days was monitored after preincubation of the extract with $50 \mu \mathrm{L}$ of $1 \mathrm{mM}$ of the inhibitor $\left(\mathrm{H}_{2} \mathrm{O}_{2}\right.$, sodium azide, $\mathrm{FeSO}_{4}$ or EDTA) for $5 \mathrm{~min}$. HRP was used as reference.

\section{Stability of the extract upon refrigeration and freezing}

Immediately after extraction, aliquots of the enzymatic extracts obtained from P. ostreatus grown for 28 days and of the residue were stored in $2-\mathrm{mL}$ flasks under refrigeration $\left(4^{\circ} \mathrm{C}\right)$ or frozen $\left(-20^{\circ} \mathrm{C}\right)$. Enzymatic activities and RBBR decolorization were measured at given time intervals.

\section{RESULTS AND DISCUSSION}

\section{Initial activity of the enzymatic extracts}

The "shimeji" mushroom is produced by Toyobo do Brasil in polypropylene flasks (about $1 \mathrm{~kg}$ ), with the substrate being completely colonized within about 30 days. This phase is followed by an additional 30 days of fructification and harvest after which the content of the flasks, corresponding to the production residue, is completely discarded. Basidiomycetes growing on solid substrates produce different patterns of hydrolytic and oxidative enzymes depending on their growth phase. For many fungi such as Agaricus bisporus, Pleurotus sajor-caju and Lentinula edodes, high laccase activities were observed during the phase of substrate colonization, with a reduction in this activity at the beginning of primordium formation $(3,15,23)$.

In agreement with these previous studies, we observed that the time of growth of $P$. ostreatus on solid substrate influenced both enzymatic activities and RBBR decolorization (Fig. 1). Maximal peroxidase and laccase activities were observed at 25 days of growth, followed by a significant reduction in these activities at 28 days. RBBR decolorization was not correlated with enzyme activity levels. RBBR decolorization by the extract obtained from P. ostreatus grown for 28 days was three times higher than that detected in the 20 -day extract, whereas its peroxidase activity was about $42 \%$ lower. The extract obtained from the shimeji culture residue did not decolorize RBBR (Fig. 1). 


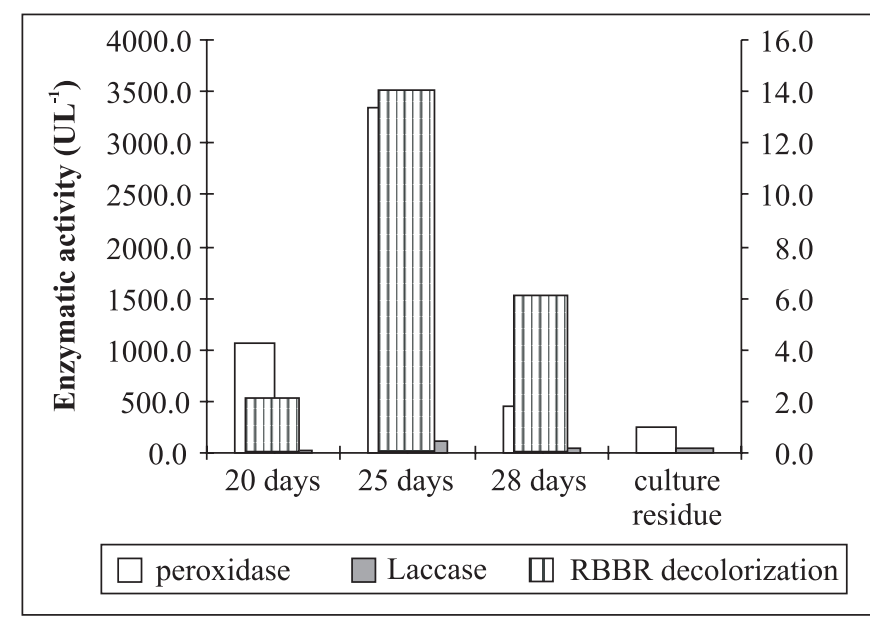

Figure 1. Peroxidase and laccase activity and decolorization of Remazol brilliant blue R (RBRR) dye by the crude extract obtained from Pleurotus ostreatus grown on solid substrate for different periods of time. One unit of decolorization activity was defined as that able to catalyze a 0.01 reduction in absorbance at $592 \mathrm{~nm}$.

The involvement of the ligninolytic system in the degradation of recalcitrant compounds by basidiomycetes is still a matter of controversy and contradictory results have been explained by inter- and intraspecies specific variations between ligninolytic systems consisting of different enzymes and mediators. Effective decolorization of RBBR by extracts obtained from Irpex lacteus grown on solid substrate (pinewood) has shown no direct relationship with $\mathrm{MnP}$ or laccase activity levels (14). However, recently a correlation has been described between ligninolytic activity and the degradation of various azo dyes by the basidiomycete PV002 (26). The presence of mediators was essential for the decolorization of RBBR by a commercial formulation of laccase used in the textile industry (24).

\section{Optimal $\mathrm{H}_{2} \mathrm{O}_{2}$ concentration and pH optimum for RBBR decolorization}

Optimal $\mathrm{H}_{2} \mathrm{O}_{2}$ concentration for RBBR decolorization by the extract obtained from $P$. ostreatus grown on solid substrate for 25 days was $50 \mu \mathrm{M}$ (Fig. 2). Peroxidases might be inactivated in the presence of $\mathrm{H}_{2} \mathrm{O}_{2}$, with this inactivation depending on the concentration of $\mathrm{H}_{2} \mathrm{O}_{2}(1,25)$. Vyas and Molitoris (27) observed that RBBR decolorization by a crude $P$. ostreatus extract was maximal at a $\mathrm{H}_{2} \mathrm{O}_{2}$ concentration ranging from 132 to $154 \mu \mathrm{M}$. Concentrations higher than $154 \mu \mathrm{M}$ inhibiting decolorization. Recently, Hoshino et al. (8) reported MnP produced by Lenzites betulinus which presented high tolerance to $\mathrm{H}_{2} \mathrm{O}_{2}$. Whereas MnP produced by $P$. chrysosporium showed maximal activity at a $\mathrm{H}_{2} \mathrm{O}_{2}$ concentration of $0.02 \mathrm{mM}$, with total loss of activity in the presence of $1 \mathrm{mM} \mathrm{H}_{2} \mathrm{O}_{2}$, the $\mathrm{MnP}$ of $L$. betulinus presented

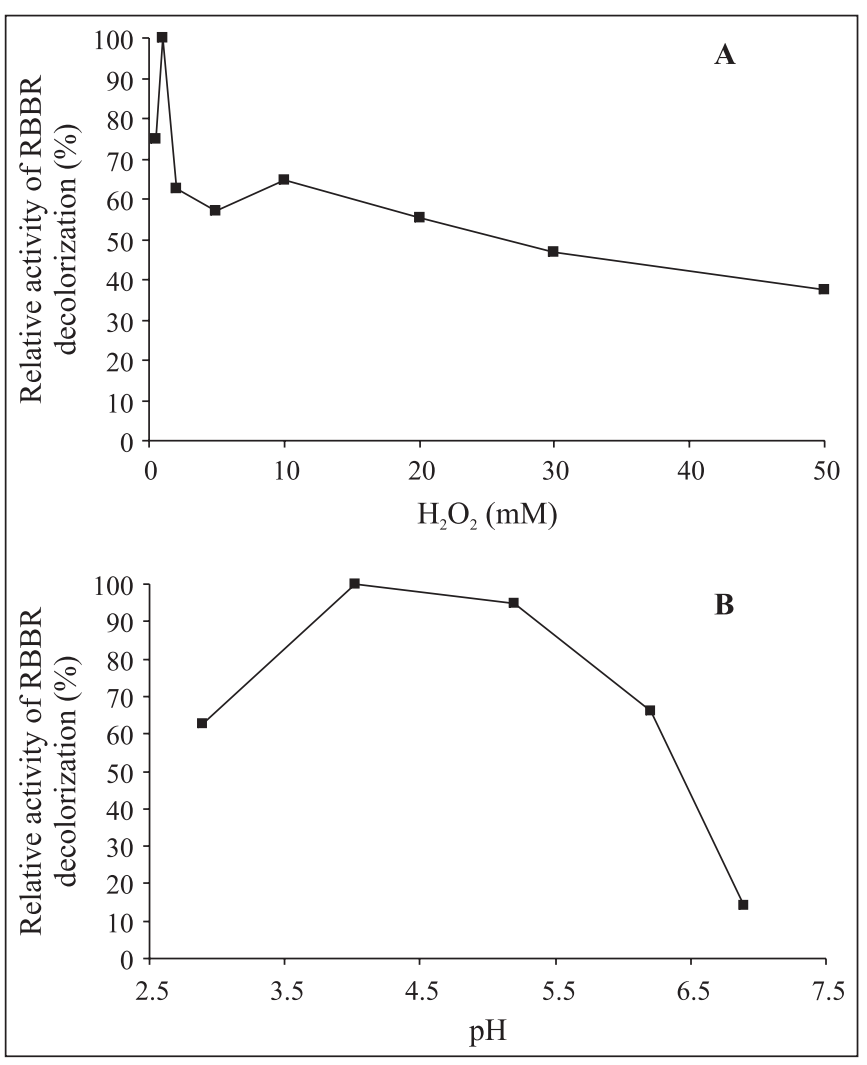

Figure 2. Optimal hydrogen peroxide concentration (A) and $\mathrm{pH}$ (B) for the decolorization of Remazol brilliant blue R (RBBR) dye by the crude extract obtained from Pleurotus ostreatus grown on solid substrate for 25 days.

maximal activity at $0.2 \mathrm{mM}$, with 95 and $60 \%$ of its activity being maintained in the presence of 1 and $10 \mathrm{mM} \mathrm{H}_{2} \mathrm{O}_{2}$, respectively. High stability in the presence of $\mathrm{H}_{2} \mathrm{O}_{2}$ is an important characteristic for the commercial application of ligninolytic enzymes $(1,8)$.

Decolorization of RBBR by the $P$. ostreatus extract was maximal at pH 4.0 (Fig. 2). Decolorization of RBBR by crude extracts and purified enzymes obtained from basidiomycetes grown on solid substrate has been shown to be maximal in the $\mathrm{pH}$ range from 4.0 to $5.0(4,22,27)$.

\section{Successive additions of RBBR}

Complete decolorization of the RBBR dye present in the reaction mixture $(0.2 \%)$ by the $P$. ostreatus extract was obtained with the addition of only one aliquot of $\mathrm{H}_{2} \mathrm{O}_{2}$, which was sufficient to decolorize newly added aliquots of RBBR corresponding to a concentration three times higher than the initial one. Crude extract of HRP was used for the effect of comparison with a typical peroxidase. Four aliquots of $50 \mu \mathrm{L}$ $\mathrm{H}_{2} \mathrm{O}_{2}$ were necessary for complete decolorization of RBBR by 
HRP (data not shown). The ability of the crude P. ostreatus extract to degrade high concentrations of RBBR with only one addition of $\mathrm{H}_{2} \mathrm{O}_{2}$ demonstrates its high biotechnological potential. The ability to decolorize high concentrations of RBBR added during successive cycles has also been observed during the growth of Irpex lacteus and P. ostreatus $(14,18)$.

\section{Effect of inhibitory substances}

Decolorization of RBBR by the P. ostreatus extract remained unchanged in the absence of $50 \mu \mathrm{L} 1 \mathrm{mM} \mathrm{H}_{2} \mathrm{O}_{2}$ in the reaction, demonstrating the involvement of laccase in this process (Table 1). This finding was supported by the significant inhibition of RBBR decolorization in the presence of typical oxidoreductase inhibitors such as sodium azide, ferrous sulfate and EDTA. Inhibition of RBBR decolorization by these agents has been reported for both crude extract and purified laccase and MnP $(4,14,22,27)$. Manganese sulfate did not alter RBBR decolorization by the $P$. ostreatus extract, as also observed by Vyas and Molitoris (27).

Oxidation of ABTS by the P. ostreatus extract was also inhibited by typical phenoloxidase inhibitors (Table 1). Manganese sulfate did not alter oxidation but EDTA inhibited the reaction by only $20 \%$. Oxidation of ABTS by laccases produced by Pycnoporus cinnabarinus and Peniophora sp. was inhibited by 100 and $95 \%$ in the presence of 0.1 and $0.5 \mathrm{mM}$ sodium azide, respectively $(6,12)$. In contrast, even high concentrations of EDTA did not inhibit ABTS oxidation by a laccase produced by Coriolus hirsutus (21). Recently, Lorenzo et al. (9) found that the inhibitory effect of EDTA on laccase activity was dependent on the substrate used. These authors

Table 1. Relative activity in terms of decolorization of the Remazol brilliant blue R (RBBR) dye and ABTS oxidation observed for the Pleurotus ostreatus extract, culture residue of this mushroom and horseradish peroxidase in the presence of inhibitory substances.

\begin{tabular}{cccccc}
\hline \multicolumn{5}{c}{ Relative activity $(\%)$} \\
\hline $\begin{array}{c}\text { Substance } \\
(1 \mathrm{mM})\end{array}$ & $\begin{array}{c}\text { P. ostreatus } \\
(25 \text { days extract })\end{array}$ & $\mathrm{HRP}$ & $\begin{array}{c}\text { P. ostreatus } \\
(25 \text { days extract })\end{array}$ & $\begin{array}{c}\text { P. ostreatus } \\
\text { (residue) }\end{array}$ & HRP \\
\hline $\mathrm{H}_{2} \mathrm{O}_{2}$ & 87 & 100 & 111 & 134 & 100 \\
$\mathrm{MnSO}_{4}$ & 100 & 31 & 100 & 246 & 94 \\
$\mathrm{NaN}_{3}$ & 0 & 66 & 0 & 15 & 92 \\
$\mathrm{FeSO}_{4}$ & 0 & 0 & 0 & 11 & 82 \\
$\mathrm{FeCl}_{3}$ & nd & 76 & 82 & 133 & 142 \\
EDTA $_{\text {Cisteína }}$ & 9 & 314 & 82 & 8 & 100 \\
control & 100 & 0 & nd & nd & nd \\
\hline
\end{tabular}

HRP: horseradish peroxidase; nd: not determined; control: containing distilled water instead of the inhibitory substance. observed a significant reduction in laccase activity in the presence of EDTA when syringaldazine or dimethoxyphenol was used, whereas no inhibition of ABTS oxidation was detected under the same experimental conditions.

In contrast to the $P$. ostreatus extract, ABTS oxidation by the culture residue extract was stimulated in the presence of $\mathrm{H}_{2} \mathrm{O}_{2}$ and $\mathrm{Mn}^{2+}$ and significantly inhibited by EDTA, demonstrating the participation of ion-dependent peroxidases such as $\mathrm{MnP}$ in the oxidation of ABTS. These results indicate significant differences in the composition of the enzymatic systems of $P$. ostreatus extracts during the different phases of growth of the fungus.

Decolorization of RBBR by HRP was stimulated by about $300 \%$ in the presence of EDTA, a finding probably due to the chelating action of the latter on metals present in the partially purified HRP extract. The influence of metals on the activity of HRP was also shown by its inhibition in the presence of manganese sulfate (Table 1).

\section{Stability of the extract upon refrigeration and freezing}

The in vitro stability of the ligninolytic complex is considered to be one of the determinant factors for the technical and economical viability of its industrial application to the degradation of pollutants, as well as for the optimization of commercial enzyme production (1). Loss of ligninolytic activity has been related to the action of proteases or inactivation by hydrogen peroxide, a metabolite produced by basidiomycetes under various culture conditions $(1,25)$.

The stability of the extracts obtained from $P$. ostreatus and from the culture residue under refrigeration and freezing was evaluated over a period of about 100 days. Keeping the $P$. ostreatus extract under refrigeration resulted in less loss of its RBBR decolorization ability and of peroxidase and laccase enzymatic activities than freezing (Fig. $3)$. Under refrigeration, reductions of only $20 \%$ in RBBR decolorization and peroxidase and laccase activities were observed at 18 days (Fig. 3A). In contrast, freezing of the $P$. ostreatus extract caused a loss of about $70 \%$ of RBBR decolorization activity and a 51 and $62 \%$ reduction of peroxidase and laccase activities, respectively, during the same period (Fig. 3B).

Although the culture residue extract did not act on RBBR at the time of its extraction (Fig. 1), decolorization of the dye by this extract was observed during refrigeration (Fig. 4). The ability of this extract to decolorize RBBR reached a maximum at 18 days, followed by a progressive loss of this activity until day 81 . Maintaining the residue extract under refrigeration also interfered with laccase activity, with maximum 

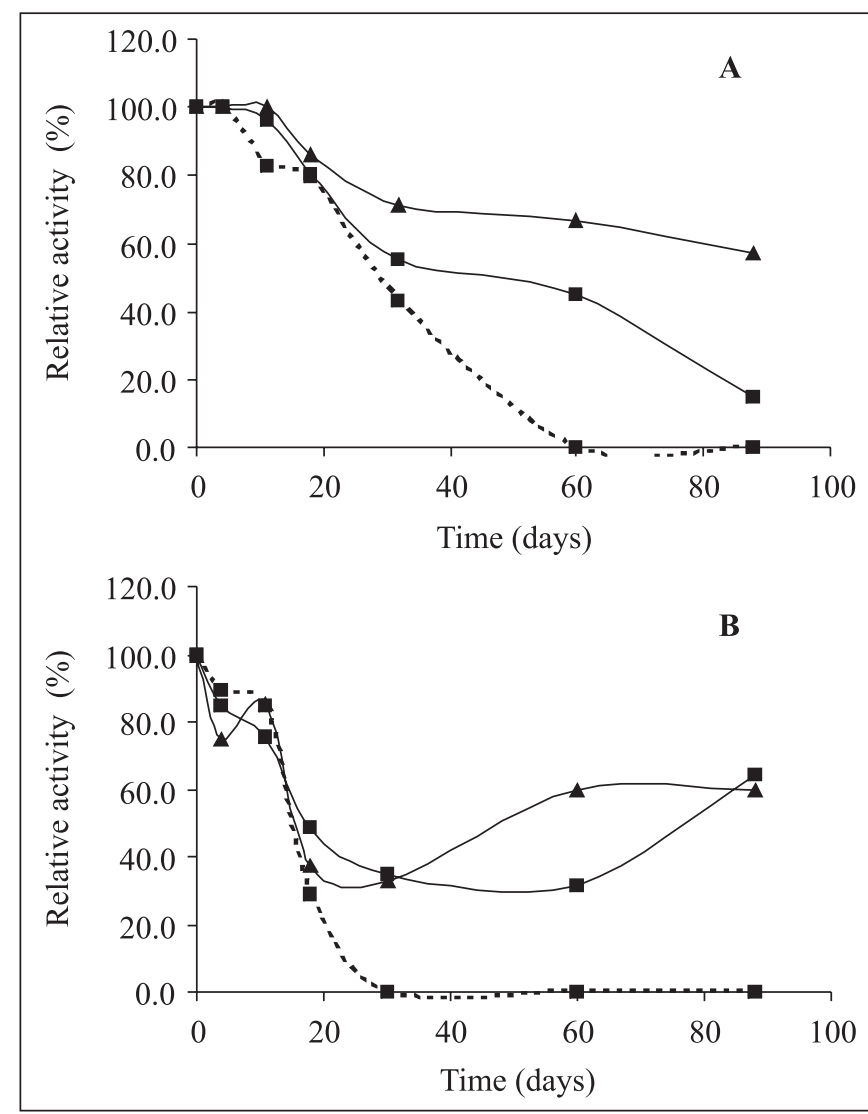

Figure 3. Residual enzymatic activity detected in the extract obtained from Pleurotus ostreatus grown on solid substrate and kept under refrigeration (A) or frozen (B). Peroxidase ( $\square$ ); laccase ( $\mathbf{\Delta})$; RBBR decolorization $(\square)$.

activity being observed at 32 days. Peroxidase activity was only affected after 30 days of refrigeration, with a loss of about $90 \%$ of its initial activity at 109 days (Fig. 4). The ability to decolorize RBBR and the increase in laccase and peroxidase activity observed during refrigeration of the extracts might be explained by the loss of inhibitory substances initially present in the extract as a result of the effect of refrigeration. When the residue extract was stored frozen, no RBBR decolorization activity was observed during a period of 109 days, and a 60 and $70 \%$ loss of laccase and peroxidase activities, respectively, was noted during the first 30 days of freezing (data not shown).

In conclusion, we demonstrated the potential application to the environmental area of enzymatic extracts obtained from $P$. ostreatus grown on solid substrate. The time of fungal growth and $\mathrm{pH}$ were the factors that most influenced the degradation of the RBBR dye, indicating the possibility to optimize the degradation process. The ability of the crude $P$. ostreatus extract to degrade high concentrations of RBBR with only one $\mathrm{H}_{2} \mathrm{O}_{2}$ addition, as well as its high stability, support the technical and

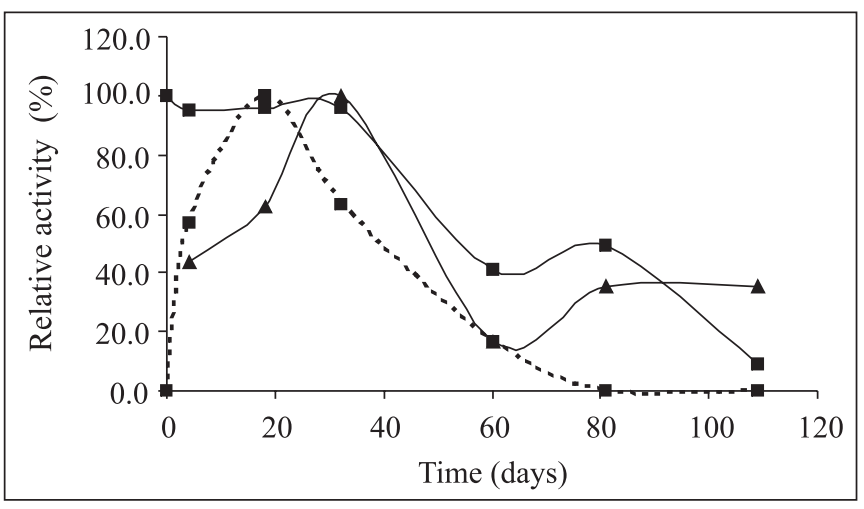

Figure 4. Residual enzymatic activity in the culture residue of Pleurotus ostreatus grown on solid substrate kept under refrigeration. Peroxidase ( $\mathbf{\square})$; laccase ( $\boldsymbol{( \Delta )}$ ); RBBR decolorization ( $\square)$.

economical viability of the industrial application of this fungus to the degradation of pollutants. Environmental application of the culture residue of mushrooms may represent an excellent form of reuse of a Brazilian agroindustrial residue.

\section{ACKNOWLEDGMENTS}

We thank Toyobo do Brasil for providing the Pleurotus ostreatus samples and the HRP enzyme.

\section{RESUMO}

\section{Biodegradação do azul brilhante de remazol $R$ pelo complexo enzimático ligninolítico produzido por Pleurotus ostreatus}

Pleurotus ostreatus ("shimeji”) é produzido no Brasil em escala comercial empregando-se vários resíduos lignocelulósicos. Esforços têm sido feitos para reaproveitamento do resíduo do cultivo em produtos de maior valor agregado, como enzimas ou sua aplicação em processos de biorremediação. Foi feita avaliação do potencial de degradação do azul brilhante de remazol (RBBR) por extratos obtidos de substratos sólidos colonizados por P. ostreatus e por extratos do resíduo da produção do cogumelo "shimeji". Substratos colonizados e o resíduo foram fornecidos pela Toyobo do Brasil Ltda. Extração foi feita com tampão acetato de sódio (50 mM, pH 4,6). Descoloração do RBBR foi acompanhada a $592 \mathrm{~nm}$ e atividades de peroxidases e lacase pela oxidação do ABTS. Peroxidase da raiz forte (HRP) foi usada como referência. O tempo de crescimento de $P$. ostreatus influenciou a degradação do RBBR e a produção das atividades enzimáticas de peroxidases e de lacase. Concentração de $1 \mathrm{mM}$ de $\mathrm{H}_{2} \mathrm{O}_{2}$ e pH 4,0 mostraram-se ótimos para descoloração do RBBR. Descoloração total do RBBR 
foi obtida com adição de apenas uma alíquota de $50 \mu \mathrm{L}$ de $\mathrm{H}_{2} \mathrm{O}_{2}$ $(1 \mathrm{mM})$. Maior estabilidade dos extratos foi obtida por refrigeração que por congelamento. Foi evidenciado o potencial de aplicação de extratos enzimáticos de Pleurotus ostreatus e do resíduo da produção do cogumelo para a degradação de compostos xenobióticos.

Palavras-chave: peroxidases, lacase, fermentação no estado sólido, resíduo do cultivo de shimeji

\section{REFERENCES}

1. Aitken, M.D.; Irvine, R.L. Stability testing of ligninase and Mnperoxidase from Phanerochaete chrysosporium. Biotechnol. Bioeng., 34, 1251-1260, 1989.

2. Bezalel, L.; Hadar, Y.; Cerniglia, C.E. Mineralization of Polycyclic Aromatic Hydrocarbons by the White Rot Fungus Pleurotus ostreatus. Appl. Environ. Microbiol., 62, 292-295, 1996.

3. Bonnen, A.M.; Anton, L.H.; Orth, A.B. Lignin-Degrading Enzymes of the Commercial Button Mushroom, Agaricus bisporus. Appl. Environ. Microbiol., 60, 960-965, 1994.

4. Deveci, T.; Unyayara, A.; Mazmanci, M.A. Production of Remazol Brilliant Blue R decolourising oxygenase from the culture filtrate of Funalia trogii ATCC200800. J. Mol. Catal. B: Enzymatic, 30, 2532, 2004.

5. Duran, N.; Esposito, E. Potential applications of oxidative enzymes and phenoloxidase-like compounds in wastewater and soil treatment: a review. Appl. Catal. B: Environm., 28, 83-99, 2000.

6. Eggert, C.; Temp, U.; Dean, J.F.; Eriksson. K.E. A fungal metabolite mediates degradation of non-phenolic lignin strutures and synthetic lignin by laccase. FEBS Lett., 5, 144-148, 1996.

7. Han, Y.-H.; Shina, K.-S.; Youn, H.-D.; Hah, Y.C.; Kang, S.-O. Mode of action and active site of an extracellular peroxidase from Pleurotus ostreatus. Biochem. J., 314, 421-426, 1996.

8. Hoshino, F.; Kajino, T.; Sugiyama, H.; Asami, O.; Takahashi, H. Thermally stable and hydrogen peroxide tolerant manganese peroxidase (MnP) from Lenzites betulinus. FEBS Lett., 530, 249 252, 2002

9. Lorenzo, M.; Moldes, D.; Rodriguez-Couto, S.; Sanroman, M.A. Inhibition of laccase activity from Trametes versicolor by heavy metals and organic compounds. Chemosphere, 60, 1124-1128, 2005.

10. Machado, K.M.G.; Bononi, V.L.R. Identificação de enzimas ligninolíticas extracelulares de basidiomicetos nativos na descoloração do corante polimérico RBBR.. In: Esposito, E. (Ed.) Proceedings of the First National Meeting of Environmental Applied Microbiology. Campinas, SP, Brazil, 1997, p.212-217.

11. Moreira, P.R.; Almeida-Vara, E.; Sena-Martins, G.; Polonia, I.; Malcata, F.X.; Duarte, J.C. Decolourisation of Remazol Brilliant Blue R via a novel Bjerkandera sp. strain. J. Biotechnol., 89, 107111,2001

12. Niku-Paavola, M.-L.; Fagerström, R.; Kruus, K.; Viikari, L. Thermostable laccases produced by a white-rot fungus from Peniophora species. Enzyme Microb. Technol., 35, 100-102, 2004.
13. Novotny, C.; Rawal, B.; Bhatt, M.; Patel, M.; Sasek, V.; Molitoris, H.P. Capacity of Irpex lacteus and Pleurotus ostreatus for decolorization of chemicaly different dyes. J. Biotechnol., 89, 113 122,2001

14. Novotyny, C.; Svobodova, K.; Erbanova, P.; Cajthaml, T.; Kasinath, A.; Lang, E.; Sasek, V. Ligninolytic fungi in bioremediation: extracellular enzyme production and degradation rate. Soil Biol. Biochem., 36, 1545-1551, 2004.

15. Ohga, S.; Royse, D.J. Transcriptional regulation of laccase and cellulase genes during growth and fruiting of Lentinula edodes on supplemented sawdust. FEMS Microbiol. Lett., 201, 111-115, 2001.

16. Okeke, B.C.; Smith, J.E.; Paterson, A.; Watson-Craik, I.A. Aerobic metabolism of pentachlorophenol by spent sawdust culture of "Shiitake" mushroom (Lentinus edodes) in soil. Biotechnol. Lett. 15, 1077-1080, 1993.

17. Ollikka, P.; Alhonmaki, K.; Leppanen, V.-M.; Glumoff, T.; Raijola, T.; Suominen, I. Decolorization of azo, triphenylmethane, heterocyclic and polimeric dyes by lignin peroxidase izoenzymes from Phanerochaete chrysosporium. Appl. Environ. Microbiol., 59, 40104016, 1993

18. Palmieri, G.; Cennamo, G.; Sannia, G. Remazol brilliant blue R decolorization by the fungus Pleurotus ostreatus and its oxidative enzymatic system. Enzyme Microb. Technol., 36, 17-24, 2005.

19. Rodriguez, E.; Nuero, O.; Guillen, F.; Martinez, A.T.; Martinez, M.J. Degradation of phenolic and non-phenolic aromatic pollutants by four Pleurotus species: the role of laccase and versatile peroxidase. Soil Biol. Biochem., 36, 909-916, 2004.

20. Semple, K.T.; Fermor, T.R. Enhanced mineralization of UL- ${ }^{14} \mathrm{C}-$ pentachlorophenol by mushroom composts. Res. Microbiol., 148, 795-798, 1997.

21. Shin, K.-S.; Lee, Y.-J. Purification and characterization of a new member of the laccase family from the white-rot basidiomycete Coriolus hirsutus. Arch. Biochem. Bioph., 384, 109-115, 2000.

22. Shin, K.-S.; Oh, I.-K.; Kim, C.-J. Production and purification of remazol brilliant blue $\mathrm{R}$ decolorizing peroxidase from the culture filtrate of Pleurotus ostreatus. Appl. Environ. Microbiol., 63, 1744 1748,1996

23. Singh, A.D.; Abdullah, N.; Vikineswary, S. Optimization of extraction of bulk enzymes from spent mushroom compost. J. Chem. Technol. Biotechnol., 78, 743-752, 2003.

24. Soares, G.M.B.; Pessoa-Amorim, M.T.; Costa-Ferreira, M. Use of laccase together with redox mediators to decolourize Remazol Brilliant Blue R. J. Biotechnol., 89, 123-129, 2001.

25. Tonon, F.; Odier, E. Influence of veratryl alcohol and hydrogen peroxide on ligninase activity and ligninase production by Phanerochaete chrysosporium. Appl. Environ. Microbiol., 54, 466472, 1988

26. Verma, P.; Madamwar, D. Decolorization of azo dyes using basidiomycete strain PV002. World J. Microbiol. Biotechnol., 21, 481-485, 2005.

27. Vyas, B.R.; Molitores, H.P. Involvement of an extracellular $\mathrm{H}_{2} \mathrm{O}_{2-}$ dependent lignolytic activity of the white rot fungus Pleurotus ostreatus in the decolorization of Remazol Brilliant Blue R. Appl. Environ. Microbiol., 61, 3919-3927, 1995.

28. Wesenberg, D.; Kyriakides, I.; Agathos, S.N. White rot fungi and their enzymes for the treatment of industrial dye effluents. Biotechnol. Adv., 22, 161-187, 2003. 